\title{
Afeksi dalam Teologi Jonathan Edwards serta Implementasinya dalam Kehidupan Kristen
}

\author{
Affections in Jonathan Edwards' Theology and \\ Its Implementation in the Christian Life
}

\author{
Grace Emilia \\ Sekolah Tinggi Teologi Bandung \\ graceemilia@sttb.ac.id
}

\begin{abstract}
Article Info
Abstract

Submitted:

Sept 12, 2020

Review Start:

Sept 13, 2020

Accepted:

Oct 3, 2020

Keywords:

Jonathan Edwards,

beauty,

The purpose of this article is to examine the term 'affections' in Jonathan Edwards' theology written in the $18^{\text {th }}$ century in one of his masterpieces, "A Treatise Concerning Religious Affections." Affection is a terminology in modern psychology, a discipline of science that just existed in the middle of the 19th century. The study, conducted using the descriptive qualitative method, tries to see whether the term carries the same meaning by exploring its background, definition, characteristic, significance and implementation in the Christian life. The conclusion shows that Edwards talks about the nature of human heart or inclination or will where ratio and emotions interact to influence decision makings. Having the right heart or holy affection is the telos of a Christian life.
\end{abstract}

affection,

heart,

solitude
[Tulisan ini bertujuan untuk mengkaji istilah 'afeksi' dalam teologi Jonathan Edwards yang ditulis pada abad ke-18 dalam salah satu karya utamanya, $A$ Treatise Concerning Religious Affections. Istilah 'afeksi' merupakan terminologi dalam psikologi modern, sebuah disiplin ilmu yang baru muncul di pertengahan abad ke-19. Studi ini menelaah apakah ada kesamaan makna dari istilah yang digunakan oleh Edwards di abad ke-18 dengan istilah itu di masa kini. Dengan menggunakan metode kualitatif deskriptif, dipelajari latar belakang, definisi, karakteristik, signifikansi, serta implementasi afeksi dalam kehidupan Kristen. Ternyata istilah ini merujuk pada natur hati manusia atau kecenderungan jiwanya atau kehendaknya, dimana rasio dan emosi berinteraksi untuk mempengaruhi pengambilan keputusan. Memiliki hati yang benar atau afeksi kudus adalah tujuan utama dari kehidupan Kristen.] 


\section{PENDAHULUAN}

$\mathbf{J}$ onathan Edwards (1703-1758) kerap dianggap sebagai teolog terbesar di Amerika Serikat. ${ }^{1}$ Banyak teolog abad ke-20 yang dipengaruhi oleh teologi Edwards, antara lain: H. Richard Niebuhr, C.S. Lewis, J.I. Packer, dan John Piper. Setidaknya, tiga dari antara berbagai karyanya, yaitu Religious Affections, Freedom of the Will, serta The Nature of the Virtue menjadi masterpiece dalam dunia literatur Kristen. ${ }^{2}$

Salah satu karya Edwards yang berpengaruh yaitu A Treatise Concerning Religious Affections membahas mengenai afeksi religius. Menurut Kamus Besar Bahasa Indonesia, 'afeksi' merupakan istilah yang merujuk pada munculnya rasa kasih sayang serta hadirnya perasaan dan emosi lunak. ${ }^{3}$ Berdasarkan definisi ini, pertanyaan yang muncul adalah apakah 'afeksi' yang dimaksud Edwards pada abad ke-18 sesuai dengan terminologi dari 'afeksi' di masa kini atau apakah berbeda sama sekali? Apakah makna dari istilah tersebut relevan dengan kehidupan Kristen di masa kini? Apa signifikansinya bagi kehidupan Kristen? Tulisan ini hendak mengkaji makna dari istilah 'afeksi religius' dalam teologi Jonathan Edwards, termasuk definisi, karakteristik, signifikansi serta implementasinya di dalam kehidupan Kristen.

\section{METODE}

Berdasarkan topik permasalahan yang hendak dikaji, penulis menggunakan pendekatan kualitatif deskriptif dengan menjadikan berbagai data literatur, termasuk buku dan jurnal, sebagai instrumen utama penelitian ini. ${ }^{4}$ Studi dokumen yang dilakukan adalah dengan mempelajari teks asli karya Jonathan Edwards yaitu A Treatise Concerning Religious Affections untuk mendapatkan pemahaman mengenai makna dari konsep afeksi menurut Edwards. Selain itu ditelaah juga teologi dan biografi Edwards yang ditulis oleh para penulis dari berbagai latar belakang untuk mendapatkan gambaran dan pemahaman yang lebih utuh mengenai latar belakang historis maupun teologis dari pemikiran Edward. Sinergi dari berbagai temuan ini memunculkan makna sesungguhnya dari istilah 'afeksi' yang digunakan oleh Edwards dan bagaimana makna itu dipahami di masa kini, termasuk definisi, karakteristik, signifikansi dan implementasinya di dalam kehidupan Kristen.

\section{PEMBAHASAN}

\section{Afeksi dalam Teologi Jonathan Edwards}

Afeksi dalam pemahaman Jonathan Edwards berkaitan erat dengan pemikiran utamanya tentang teologi keindahan, walaupun Edwards sendiri tidak pernah menyebutnya demikian. Sejarawan Patrick Sherry menyatakan bahwa Edwards menjadikan keindahan sebagai hal utama yang mendasari teologinya, lebih dari siapa pun dalam sejarah pemikiran Kristen. ${ }^{5}$ Keindahan yang

\footnotetext{
${ }^{1}$ Gerald R. McDermott, "Introduction: How to Understand the American Theologian," in Understanding Jonathan Edwards: An Introduction to America's Theologian (Oxford: Oxford University Press, 2009).

${ }^{2}$ George A. Marsden, "Biography," in The Cambridge Companion to Jonathan Edwards, ed. Stephen J. Stein (Cambridge: Cambridge University Press, 2007), 23.

${ }^{3}$ KBBI Daring, "Afeksi," n.d.

${ }^{4}$ Sonny Eli Zaluchu, "Strategi Penelitian Kualitatif Dan Kuantitatif Di Dalam Penelitian Agama," Evangelikal: Jurnal Teologi Injili Dan Pembinaan Warga Jemaat, 2020, https://doi.org/10.46445/ejti.v4i1.167.

${ }^{5}$ McDermott, "Introduction: How to Understand the American Theologian."
} 
dimaksud oleh Edwards bukan merujuk pada keindahan seni murni atau seni rupa, tapi merujuk pada esensi Allah. Bagi Edwards, karakteristik Allah yang paling nyata adalah keindahan ilahNya. Ia mengidentifikasi tujuh atribut yang menunjukan keindahan Allah yaitu: keabadian dan eksistensi-Nya, kebesaran-Nya, kemegahan-Nya, kuasa-Nya, hikmat-Nya, kekudusan-Nya, dan kebaikan-Nya. ${ }^{6}$

Dengan kata lain, keindahan bersifat fondasional dalam pemahaman Edwards tentang keberadaan (being). Baginya, keindahan adalah prinsip pertama dari keberadaan. ${ }^{7}$ Di abad ke-20, filsuf Erich Fromm menjelaskan tentang prinsip mengada (to be) yang merupakan modus eksistensi dimana seseorang tidak mempunyai apa-apa, tapi bisa bersukacita dalam menggunakan panca indranya secara maksimal untuk bisa menyatu dengan dunia. Mengada ini berakar dari pengalaman manusia yang tidak dapat dipelajari hanya dengan rasio semata tapi dari pengalaman konkret yang terwujud dalam keseharian. ${ }^{8}$ Jonathan Edwards bisa mengada dengan mengenal dan mencintai Allah melalui mengenal dan mencintai keindahan Allah yang merupakan sumber dan dasar dari keindahan sejati.

Ketika menusia menangkap keindahan Allah, maka hal itu akan berdampak pada munculnya afeksi religius berupa sukacita dan kasih terhadap Allah yang bisa memikat dan mengubah manusia. ${ }^{9}$ Pemikiran mendalam Edwards tentang hal ini menyebabkannya dianggap sebagai 'nabi modernitas' oleh Perry Miller, seorang penulis dari Harvard yang menulis tentang para pemikir di New England, daerah asal Edwards. ${ }^{10}$ Disebut nabi modernitas karena Edwards mengintegrasikan pemahamannya akan relasi Allah dengan jiwa manusia jauh melebihi jamannya.

Setidaknya terdapat dua pemicu yang mendasari pemikiran Edwards mengenai afeksi dalam teologi keindahannya ini. Pertama, pengalaman pribadi Edwards. Mardsen, salah seorang penulis biografi Edwards menyatakan bahwa refleksi teologis dan filsafat Edwards berkaitan erat dengan pengalaman religius pribadinya. ${ }^{11}$ Memang sejak ia bertobat sampai selama dua tahun berikutnya (1721-1723), Edwards mengalami sukacita rohani yang menjadikan kehidupan Kristennya begitu mengagumkan. Hal ini memotivasinya untuk menjelaskan pengalamannya ini dalam istilah-istilah filosofis dan teologis. ${ }^{12}$

Kedua, perjuangan Edwards dalam melawan filsafat Deisme yang muncul dengan sangat kuat di jaman tersebut. Para politikus bahkan founding fathers yang berpengaruh besar dalam sejarah Amerika Serikat pada masa Edwards hidup adalah penganut Deisme, seperti misalnya Benjamin Franklin, Thomas Paine dan Thomas Jefferson. ${ }^{13}$ Filsafat Deisme meyakini bahwa

\footnotetext{
${ }^{6}$ Owen Stratchan and Doug Sweeney, Jonathan Edwards on Beauty (Chicago: Moody Publishers, 2010).

${ }^{7}$ Michael J. McClymond and Gerald R. McDermott, The Theology of Jonathan Edwards (Oxford: Oxford University Press, 2012). 2019).

${ }^{8}$ Erich Fromm, Mempunyai Atau Mengada, ed. Muhammad Ali Fakih (Yogyakarta: IRCiSoD,

${ }^{9}$ Paulus Eko Kristianto, "Memahami Konstruksi Teologi Keindahan,” KURIOS (Jurnal Teologi

Dan Pendidikan Agama Kristen) 5, no. 2 (2019): 151-65.

${ }^{10}$ McDermott, "Introduction: How to Understand the American Theologian."

${ }^{11}$ Marsden, "Biography."

12 James H. Thomforde, "Defending Happiness: Jonathan Edwards's Enduring Pursuit of a Reformed Teleology of Happiness" (The University of Edinburgh, 2018).

${ }^{13}$ Donald Wayne Viney, "American Deism, Christianity, and the Age of Reason," American Journal of Theology \& Philosophy 31, no. 2 (2010): 83-107, https://doi.org/10.1353/ajt.0.0005.
} 
Allah adalah pencipta yang tidak hadir. Ia hanya memulai proses kosmik dari alam semesta, tapi lalu membiarkannya berjalan dengan sendirinya tanpa terlibat lagi sama sekali. Allah juga hanya berkomunikasi melalui alam dan rasio. ${ }^{14}$ Karena itu bagi manusia, hanya rasio saja yang dapat mewujudkan agama sejati. Berbagai masalah yang terjadi di dalam kehidupan beragama serta di dalam relasi antar manusia pada umumnya merupakan kegagalan dari penggunaan rasio secara tepat.

Edwards meresponi pemikiran ini dengan menekankan bahwa motivasi manusia berakar jauh lebih dalam dari sekedar pemikiran rasional. Lagipula, tidak ada yang disebut sebagai rasio yang netral karena pemikiran manusia sudah digelapkan atau dijadikan tidak mampu oleh dosa. Dengan demikian, rasio manusia sudah terkontaminasi oleh kepentingan diri. Tak heran jika orang-orang pandai justru menjadi mereka yang paling bertanggung-jawab pada terjadinya berbagai kejahatan besar. ${ }^{15}$

Edwards meyakini bahwa hal utama yang menggerakkan segala tindakan manusia adalah afeksi bukan rasio. Di bagian pertama dari Religious Affections Edwards menyatakan bahwa agama sejati terdiri dari afeksi kudus. Ia menjelaskan mengenai hal ini dengan pertama-tama membahas tentang kapasitas jiwa manusia. Menurut Edwards, terdapat dua kapasitas jiwa manusia. Kapasitas pertama mampu menangkap persepsi dan berspekulasi, terrmasuk dapat menilai berbagai hal sehingga disebut sebagai kapasitas untuk memahami. Sementara kapasitas kedua disebut sebagai afeksi. Afeksi ini merupakan kehendak atau kecenderungan (inklinasi) kuat yang dapat mempengaruhi pengambilan keputusan dari suatu tindakan. Dengan demikian, segala sesuatu yang kita kerjakan selalu merupakan hasil dari kehendak atau inklinasi diri kita yang mengatur berbagai tindakan kita. Edwards mengakui bahwa afeksi ini sering dirujuk dengan menggunakan berbagai sebutan. Kadang disebut sebagai inklinasi, tapi dalam hubungannya dengan berbagai tindakan yang dikendalikan oleh diri disebut sebagai kehendak, sementara yang berhubungan dengan perwujudan pikiran disebut sebagai hati. ${ }^{16}$ Di awal abad ke-21 ini, ide tentang hati sebagai pengendali utama dari berbagai keputusan yang diambil manusia dipopulerkan kembali terutama oleh teolog dan filsuf Dallas Willard. ${ }^{17}$

Edwards menjelaskan lebih lanjut tentang natur dari afeksi atau hati sebagai yang terdiri dari spekulasi (baca: rasio) yang merupakan pelaksana kehendak dan terdiri dari apa yang di jaman sekarang dikenal dengan istilah emosi, walau Edwards tidak menyebutnya demikian. Dengan kata lain, afeksi terdiri atas integrasi rasio dan emosi. Edwards menyatakan merupakan hal yang alamiah untuk manusia dipengaruhi oleh afeksi tertentu seperti misalnya cinta, benci, rindu, antisipasi, takut atau yang lainnya. Edwards meyakini bahwa afeksi-afeksi inilah yang menggerakkan manusia untuk bertindak dan mengejar berbagai hal. Untuk membuktikan tentang hal ini, Edward menantang pembacanya untuk menghilangkan semua yang disebut afeksi, maka ia yakin bahwa dunia tidak akan bergerak dan mati. Edwards menyatakan, jika cinta dan kebencian, harapan dan rasa takut, kemarahan, semangat, serta kerinduan diambil, maka dunia

\footnotetext{
${ }^{14}$ Gerald R. McDermott, "Jonathan Edwards, Deism, and the Mystery of Revelation," Journal of Presbyterian History (1997) 77, no. 4 (1997): 211-24.

${ }^{15}$ McDermott, "Introduction: How to Understand the American Theologian."

${ }^{16}$ Jonathan Edwards, A Treatise Concerning Religious Affections in Three Parts (Grand Rapids, MI.: Christian Classics Ethereal Library, n.d.).

17 Steve L Porter, "The Willardian Corpus," Journal of Spiritual Formation and Soul Care 3, no. 2 (2010): 239-66.
} 
akan berhenti bergerak dan mati. Ia meyakini, tidak akan ada lagi aktivitas di antara umat manusia, atau pengejaran kerinduan yang tulus di antara manusia. ${ }^{18}$

Dari penjelasan di atas dapat dilihat bahwa melalui istilah afeksi ini terdapat interaksi antara rasio dan emosi yang memunculkan kehendak. Contoh interaksi semacam ini dalam konteks kehidupan masa kini: seseorang merasa takut (= emosi) ketika terjadi wabah penyakit. Secara rasional ia paham bahwa sifat wabah adalah menular dan berpotensi menyebabkan kematian, dan bahwa ia pun tidak terlepas dari kemungkinan tertular. Interaksi dari rasio dan emosi seputar hal ini memunculkan afeksi yang bersifat antisipatif, dimana ia berkehendak untuk menjaga dirinya dengan misalnya sering mencuci tangan dan menghindari kerumunan orang. Di Alkitab, interaksi antara rasio dan emosi di hati manusia bisa memunculkan hasil yang berbeda: "Hati yang gembira adalah obat yang manjur, tetapi semangat yang patah mengeringkan tulang." 19

\section{Dua Jenis Afeksi dan Signifikansinya bagi Kehidupan Kristen}

Edward membedakan afeksi menjadi dua jenis, yaitu afeksi spiritual atau yang disebutnya sebagai afeksi sejati atau afeksi kudus, serta afeksi non-spiritual atau yang disebutnya sebagai afeksi duniawi. Edwards yang pendekatannya di area ini cenderung Platonis karena membedakan antara yang spiritual dan non-spiritual, meyakini jika afeksi duniawi menjadi penggerak dari berbagai tindakan manusia, maka hal serupa terjadi pula di ranah religius. Karena itu bagi Edwards, jika seseorang hanya memiliki pemahaman doktrinal tapi tidak memiliki afeksi, maka ia tidak akan bisa menjalani kehidupan religius yang sejati. ${ }^{20}$ Ia memulai penjelasannya ini dengan membahas mengenai afeksi sejati:

\section{Afeksi Sejati atau Kudus}

Edwards menunjukkan maksud dari kehidupan religius yang sejati ini dengan membahas dari Perjanjian Baru: "Sekalipun kamu belum pernah melihat Dia, namun kamu mengasihi-Nya. Kamu percaya kepada Dia, sekalipun kamu sekarang tidak melihat-Nya. Kamu bergembira karena sukacita yang mulia dan yang tidak terkatakan." ${ }^{21}$ Konteks dari ayat ini adalah tentang Rasul Petrus ang menyatakan sikap orang Kristen yang bisa tetap mengasihi dan bersukacita walaupun mengalami penderitaan. Edwards menyatakan tidak ada kata-kata manusia yang dapat menggambarkan maksud dari sukacita ini. Ia hanya bisa mengekspresikannya dengan sebutan "sukacita yang penuh kemuliaan." Edwards lalu menggambarkan kondisi orang-orang yang dipenuhi oleh sukacita yang penuh kemuliaan ini dengan menggambarkan bahwa pikiran mereka seperti dipenuhi oleh terang yang sarat oleh kemuliaan, dimana kondisi alamiah mereka dimuliakan dan disempurnakan.

Sukacita yang didapatkan berbeda dari sukacita ketika pikiran dipenuhi oleh berbagai kesenangan jasmani. Sebab yang terjadi adalah yang sebaliknya, dimana sukacita ini justru memperindah dan menaikkan martabat pikiran dan membuat seseorang mencicipi sebagian kecil dari sukacita surgawi yang membawa pikiran kepada kondisi yang dipenuhi oleh berkat surgawi dan terang kemuliaan Allah. Itulah sebabnya, agama yang sejati pasti memiliki afeksi kudus berupa kasih kepada Kristus dan sukacita di dalam Kristus. Hal ini bisa dilihat dari orang-orang

\footnotetext{
${ }^{18}$ Edwards, A Treatise Concerning Religious Affections in Three Parts.

${ }^{19}$ Amsal 17:22.

${ }^{20}$ Edwards, A Treatise Concerning Religious Affections in Three Parts.

${ }^{21} 1$ Petrus 1:8.
} 
Kristen yang menghadapi persekusi. Mereka bisa bertahan seperti emas yang dimurnikan oleh api karena adanya afeksi kudus berupa kasih dan sukacita di hati mereka. ${ }^{22}$

Salah satu contoh nyata dari hal ini di masa kini terjadi pada orang-orang Kristen di Eurasia (mantan Uni Soviet). Dengan tingginya kasus penderita pandemi COVD19, menginfeksi 640 ribu jiwa di kawasan itu pada Juli 2020, pemerintah setempat melakukan lockdown. Namun di masa-masa sulit ini, gereja-gereja Injili justru menjadi terang karena telah 'terlatih' selama lebih dari 70 tahun mengalami 'lockdown' dan persekusi di bawah pemerintah komunisme yang kondisinya jauh lebih buruk dari wabah penyakit di masa kini. Seorang gembala jemaat dari Ukraina menceritakan berbagai pertolongan dan damai sejahtera yang Tuhan berikan bagi gerejaNya di masa penuh aniaya ketika di bawah Uni Soviet dulu. ${ }^{23}$

Dari penjelasan dan contoh ini terlihat korelasi yang kuat antara afeksi dengan mengalami keindahan Allah. Walaupun situasinya tampak kontradiktif (ada persekusi dan kesusahan), tapi orang Kristen masih bisa tetap bersukacita karena kasih dan sukacita yang menjadi sumber utama kebahagiaan berasal dari kemampuan batin mereka untuk menikmati Allah dan keindahan-Nya. Ketika manusia menerapkan hal itu, maka Allah dipermuliakan dan ditinggikan. ${ }^{24}$

Dengan demikian bagi Edwards, tujuan ultimat Injil bukan untuk melakukan yang baik bagi kemuliaan Allah, tapi untuk mengalami afeksi sukacita sejati. Bahkan bisa dikatakan bahwa baginya, mengalami sukacita sejati merupakan telos dari karya keselamatan Kristus, sebab sumber dari sukacita ini adalah Allah sendiri. Pada awalnya Edwards menyatakan bahwa tujuan dari kehidupan Kristen adalah memuliakan Allah dan melakukan hal-hal yang baik bagi sesama. Hal ini terdapat di karyanya seperti misalnya Christian Happiness (1721). Namun setahun kemudian dalam Resolution No. 1 (1722) terjadi pergeseran teologi, dimana Edwards menyatakan bahwa tujuan dari kehidupan Kristen adalah memuliakan Allah dengan sebanyak mungkin mendapatkan sukacita yang baik dan menguntungkan bagi dirinya, yang diusahakan dengan segala kuasa, kekuatan, daya kemampuan dan semangat. ${ }^{25}$

Edwards menyimpulkan demikian karena berdasarkan pengalaman pribadinya, ketika ia berfokus pada sukacita sejati, maka ia mengalami rasa haus dan kerinduan yang membakar untuk bisa hidup utuh sebagai orang Kristen, yaitu untuk bisa menjadi semakin seperti gambaran Kristus. Atau dengan kata lain, afeksi sejati akan secara alamiah menghasilkan serta mewujudkan roh kasih, lemah lembut, ketentraman, pengampunan dan belas kasihan seperti yang terdapat di dalam Kristus. ${ }^{26}$ Edwards lalu membahas dua cara Allah dimuliakan melalui sukacita umat-Nya ini. Cara pertama adalah dengan mewahyukan diri-Nya kepada pemahaman rasional manusia. Sementara cara kedua adalah dengan mengkomunikasikan diri-Nya kepada hati manusia melalui sukacita dan kegembiraan yang mereka nikmati dari kehadiran-nya. Dengan kata lain, Allah dipermuliakan ketika manusia menikmati kemuliaan Allah itu. ${ }^{27}$

${ }^{22}$ Edwards, A Treatise Concerning Religious Affections in Three Parts.

${ }^{23}$ Michael Cherenkov, "5 Pandemic Lessons from Eurasia's Evangelical Churches," Christianity Today, July 2020.

${ }^{24}$ John Piper, God's Passion for His Glory: Living the Vision of Jonathan Edwards (Wheaton: Crossway Books, 1998).

${ }^{25}$ Thomforde, "Defending Happiness: Jonathan Edwards's Enduring Pursuit of a Reformed Teleology of Happiness."

${ }^{26}$ Myra Jehlen and Michael Warner, eds., "Jonathan Edwards: Personal Narrative," in The English Literatures of American 1500 - 1800 (New York and London: Routledge, 1997), 609.

${ }^{27}$ John Piper, Mendambakan Allah: Meditasi Seorang Hedonis Kristen, ed. Elifas Gani (Surabaya: Penerbit Momentum, 2008). 
Itulah sebabnya bagi Edwards, manusia membangun cita rasa ini dengan segala usaha dan kemampuannya, yaitu untuk sebanyak mungkin mendapatkan kepuasan rohani. ${ }^{28}$ John Piper yang mengaku sebagai pewaris pemikiran Edwards mengatakan bahwa pemahaman tentang hal ini mencengangkan dirinya karena ternyata, mengkonsumsi kesenangan (baca: afeksi sukacita) adalah tujuan ultimat manusia. ${ }^{29}$ Piper meyakini bahwa pemikiran Edwards ini menolong mengatasi antroposentrisme yang dihidupi dengan kuat oleh masyarakat kontemporer yang sangat berfokus pada mencintai diri sendiri. Anugerah yang berpusat pada Allah justru menghanguskan injil-injil yang berfokus kepada membangun kepercayaan pada diri sendiri. ${ }^{30}$

\section{Afeksi Palsu}

Edwards juga memperingatkan tentang keberadaan dan bahaya dari afeksi palsu. Afeksi palsu antara lain terwujud ketika praktik latihan Kristen diterapkan sebagai formalitas belaka. Ia menyebutnya sebagai pertunjukan penuh cahaya yang dikagumi oleh banyak orang tapi yang sebetulnya bukan apa-apa. Bagi Edwards hal ini berbahaya karena bisa membawa agama pada formalitas yang tidak bernyawa, sebab ujung-ujungnya, afeksi semacam ini akan menyebabkan orang mencari kepentingan diri sendiri, memuja diri sendiri dan selalu bertengkar dengan orang lain. Edwards menyebut orang-orang yang menjalani agama yang bersifat formalitas ini sebagai orang Farisi yang tidak memiliki kasih Allah di dalam diri mereka. ${ }^{31}$ Orang Farisi di sini merujuk pada sekte Yahudi di jaman Perjanjian Baru yang sangat mementingkan ritual dan kesalehan eksternal seperti berdoa, berpuasa, atau memberi sedekah, tapi mengabaikan kesalehan batin yang kadang tidak langsung terlihat dari luar. ${ }^{32}$

Edwards juga meyakini ketika seseorang menghidupi afeksi palsu, maka kerangka pikirnya menjadi tidak terlalu terpengaruh lagi oleh dosa-dosa di masa kini dan di masa lalu, serta tidak terlalu peka akan kemungkinan berdosa di masa depan. Orang semacam ini tidak terlalu peduli dan tidak tergerak lagi oleh Firman Tuhan atau pada hukuman-Nya, gegabah dalam menjaga hati serta sikap, tidak bisa secara cepat membedakan apakah sesuatu berdosa atau tidak, dan tidak takut lagi pada kehadiran si jahat. ${ }^{33}$ Alkitab Perjanjian Baru menyebutnya sebagai perasaan yang telah tumpul, dimana orang-orang yang demikian menyerahkan diri kepada hawa nafsu dan mengerjakan dengan serakah segala macam kecemaran. ${ }^{34}$

Wujud lain dari afeksi palsu adalah adanya berbagai bentuk afeksi berintensitas tinggi yang dialami oleh seseorang dari waktu ke waktu, tapi yang tidak membawa efek jangka panjang. Edwards menjelaskan bahwa wujud dari afeksi semacam ini bisa berupa emosi berintensitas tinggi yang kadang tampaknya begitu mengangkat, tapi tiba-tiba lalu menghilang sampai seperti mati dan meninggalkan sensasi kosong. ${ }^{35}$ Edwards mencontohkan dari kasus orang-orang Israel yang memberikan pujian kepada Allah sebelum menyembah Anak Lembu Emas. Atau seperti orang-orang yang memuji Yesus Kristus ketika Ia masuk ke Yerusalem dengan mengendarai

\footnotetext{
${ }^{28}$ Piper, God's Passion for His Glory: Living the Vision of Jonathan Edwards.

${ }^{29}$ Piper, Mendambakan Allah: Meditasi Seorang Hedonis Kristen.

${ }^{30}$ Piper, God's Passion for His Glory: Living the Vision of Jonathan Edwards.

${ }^{31}$ Edwards, A Treatise Concerning Religious Affections in Three Parts.

${ }^{32}$ Yayasan Lembaga SABDA, "Farisi," Studi Kamus Alkitab SABDA, n.d.

${ }^{33}$ Edwards, A Treatise Concerning Religious Affections in Three Parts.

34 Efesus 4:19

${ }^{35}$ Edwards, A Treatise Concerning Religious Affections in Three Parts.
} 
seekor keledai. Tetapi orang-orang yang sama itu jugalah yang di kemudian waktu berteriak, "salibkah Dia, salibkan Dia." 36

Contoh perwujudan dari hal ini di masa kini, antara lain ketika seorang musisi populer yang telah menulis dan memimpin lagu-lagu pujian terkenal yang begitu mengangkat 'emosi' di berbagai ibadah penyembahan, menyatakan bahwa ia meninggalkan imannya. Sejak pengumumannya itu, ia berkali-kali mengekspresikan keraguannya tentang Allah di media sosial. ${ }^{37}$ Musisi bisa membangun afeksi berintensitas tinggi yang begitu mengangkat, tapi pada akhirnya ia sendiri tidak menghidupi afeksi sejati di dalam Kristus.

Dengan demikian, ringkasan dari penjelasan Edwards mengenai afeksi sejati atau kudus vs. afeksi palsu adalah sebagai berikut: Kecenderungan kudus akan membawa seseorang untuk mengasihi Allah dengan perasaannya, berpikir benar tentang Allah dengan pikirannya, serta menaati berbagai perintah-Nya dengan tindakan berdasarkan kehendaknya. Sementara afeksi yang tidak kudus akan menyebabkan seseorang membenci iman dan kekristenan dengan perasaannya, percaya bahwa ada berbagai alasan yang baik untuk menolak iman dengan pikirannya, dan menolak untuk berdoa atau mengikuti ibadah di gereja atau juga menolak adanya pengaruh agama di dalam masyarakat melalui tindakan kehendaknya. ${ }^{38}$

\section{Cara Mendapatkan Afeksi Kudus}

Pertanyaan berikutnya, bagaimana caranya agar seseorang bisa memahami dan mengalami keindahan ilahi yang menghasilkan afeksi kudus ini? Sebagai seseorang yang mengimani kedaulatan Allah, Edwards meyakini bahwa keindahan ilahi adalah sepenuhnya anugerah yang diberikan oleh Allah Tritunggal melalui Allah Roh Kudus. Anugerah adalah pemberian yang diberikan dari Allah pencipta kepada manusia ciptaan yang lebih rendah yang sebetulnya tidak layak untuk menerimanya. ${ }^{39}$ Manusia tidak memiliki kemampuan alamiah untuk bisa menerima sensasi ilahi. Dia-lah yang pertama-tama harus menaruh kemampuan tersebut. Dengan kata lain, anugerah di dalam hati tidak dihasilkan oleh kekuatan sendiri atau merupakan efek alamiah dari kemampuan manusiawi, melainkan hasil dari karya Roh Allah. Roh Allah yang menyelamatkan itulah yang pertama memberikan persepsi atau sensasi batin baru di pikiran seorang manusia yang dikuduskan oleh-Nya, yang secara natur menjadi berbeda sama sekali dari sebelum hal itu terjadi. ${ }^{40}$

Rasul Paulus menjelaskan tentang hal ini dengan menyatakan bahwa orang Kristen mencerminkan kemuliaan Tuhan yang berasal dari Roh Allah, yang mengubah orang Kristen menjadi serupa dengan gambar-Nya, dalam kemuliaan yang semakin besar. ${ }^{41}$ Sementara itu Edwards mengistilahkan proses ini sebagai memberi sensasi baru, memberi mata untuk melihat, memampukan telinga untuk mendengar, mencelikkan mata yang terlahir buta, serta membawa seseorang dari kegelapan kepada terang. Atau bisa juga diekspresikan dengan ungkapan 'membangkitkan seseorang dari kematian menjadi ciptaan baru.' Ketika seseorang sudah menjadi

\footnotetext{
${ }^{36}$ McClymond and McDermott, The Theology of Jonathan Edwards.

${ }^{37}$ Carol Kuruvilla, “Evangelical Songwriter Says He's No Longer Christian In Emotional Instagram Post," Huffpost.com, 2019.

${ }^{38}$ McClymond and McDermott, The Theology of Jonathan Edwards.

${ }^{39}$ Djoko Sukono, “Teologi 'Manusia Baru’ Relevankah Di Era Milenial,” PASCA: Jurnal Teologi Dan Pendidikan Agama Kristen 15, no. 2 (2019): 39-44.

${ }^{40}$ Edwards, A Treatise Concerning Religious Affections in Three Parts.

412 Korintus 3:18
} 
ciptaan baru, maka jiwanya akan bisa menangkap keindahan Allah dan kemuliaan Kristus yang luar biasa. Ia menjadi memiliki kerinduan akan Allah serta rasa lapar dan haus akan kemuliaanNya. ${ }^{42}$

Dalam otobiografinya yang berjudul Personal Narrative, Edwards menceritakan contoh nyata tentang hal ini berdasarkan pengalaman pribadinya. Di situ ia menceritakan ketika masih seorang anak muda, ia mengalami kesenangan dari melakukan tugas-tugas religius. Ia menuliskan bahwa pada saat itu, baik ia maupun banyak orang lain menganggap itulah yang disebut anugerah.

${ }^{43}$ Dengan kata lain, sumber dari kebahagiaan Edwards pada masa itu bukan Tuhan tapi melakukan tugas-tugas untuk Tuhan. Edwards menamai kesenangan semacam itu sebagai kesenangan yang didasarkan oleh kebenaran diri sendiri. Tetapi pemahamannya ini berubah ketika ia mengalami konversi, dimana ia mengalami sukacita yang disebutnya sebagai 'keyakinan yang membahagiakan'. Sesudah peristiwa tersebut, Edwards tidak pernah keluar dari keyakinannya bahwa afeksi sukacita sejati hanya dimiliki oleh seseorang yang telah terlebih dahulu mengalami regenerasi yang merupakan anugerah Allah semata. ${ }^{44}$

Penjelasan Edwards yang paling terkenal mengenai hal ini terdapat di dalam karyanya Divine Light, dimana Edwards membahas tentang rasa madu. Edwards menjelaskan bahwa ada perbedaan antara memberikan penilaian rasional tentang rasa manis madu dan merasakan sendiri manisnya rasa madu. Seseorang mungkin bisa melakukan yang pertama, tapi ia tidak betul-betul tahu bagaimana rasa madu yang sesungguhnya. Seseorang tidak bisa mengalami hal yang kedua itu kecuali ia sudah punya gagasan tentang bagaimana rasa madu itu di dalam pikirannya. ${ }^{45}$

\section{Membangun Afeksi Kudus Melalui Praktik Latihan Rohani}

Pertanyaan berikutnya, bagaimana membangun afeksi kudus sehingga seseorang bisa dengan segala daya dan upaya membangun sukacita sejati yang memuliakan Allah? Edwards meyakini bahwa afeksi kudus bisa berkembang dan menguat melalui praktik yang di jaman sekarang disebut sebagai disiplin rohani, walaupun Edwards tidak menyebutnya demikian. Dalam berbagai tulisan essay maupun naskah khotbahnya, ia merujuk pada disiplin rohani sebagai 'latihan praktik Kristen'.

Edwards mengatakan bahwa derajad dari kehidupan beragama dinilai dari keteguhan dan kekuatan seseorang dalam menerapkan kebiasaan berlatih yang membangun afeksi. Walau tentu saja, latihan rohani dapat mengubah natur (karakter) seorang Kristen karena ada Roh Krisus yang bertahta di dalam hatinya. Edwards menegaskan tentang hal ini dengan menyatakan bahwa anugerah sejati bukan berarti manusia tidak aktif. Proses regenerasi yang merupakan karya Allah pemberi anugerah berkaitan langsung dengan adanya praktik oleh manusia. ${ }^{46}$

Sayangnya, tidak banyak karya Edwards yang menunjukkan bagaimana ia menghidupi praktik yang menghasilkan afeksi kudus ini, kecuali dari tulisan-tulisan pendek otobiografinya seperti Personal Narrative dan Diary, atau tulisan mengenai misionaris yang mati muda, David Brainerd, yang jurnal hariannya diedit dan dipublikasikan oleh Edwards. McClymond yang

${ }^{42}$ Edwards, A Treatise Concerning Religious Affections in Three Parts.

43 Jehlen and Warner, "Jonathan Edwards: Personal Narrative."

${ }^{44}$ Michael J. McClymond, Encounters with God: An Approach to the Theology of Jonathan Edwards (New York: Oxford University Press, 1998).

${ }^{45}$ McClymond and McDermott, The Theology of Jonathan Edwards.

${ }^{46}$ Edwards, A Treatise Concerning Religious Affections in Three Parts. 
menulis mengenai spiritualitas Edwards menyatakan bahwa Edwards memang cenderung membangun afeksi kudusnya secara soliter dan kontemplatif. Salah satu bukti yang menunjukkan identitas Edwards sebagai seorang yang cenderung kontemplatif adalah penggunaan istilah 'kontemplasi' yang diulang hingga 13 kali dalam Personal Narrative-nya. ${ }^{47}$ Kecenderungan soliter Edwards juga dapat dilihat dari tulisan-tulisan otobiografinya, dimana ia tidak menceritakan relasinya dengan keluarga, gereja, atau teman-temannya. John Piper bahkan menyatakan bahwa Edwards mungkin bukan seorang gembala jemaat yang ideal karena ia terlalu banyak melakukan studi dan terlalu sedikit berelasi dengan jemaat. Tetapi memang melalui karyakaryanya, ia telah menjadi gembala bagi banyak jemaat yang lapar hingga masa kini. ${ }^{48}$

Terlepas dari kecenderungan kepribadian Edwards yang soliter yang mempengaruhi cara ia membangun hatinya, bagian terakhir dari tulisan ini akan sedikit mengangkat beberapa praktik rohani yang dilakukan oleh Edwards dalam ia membangun afeksi kudusnya, antara lain:

\section{Praktik Rohani: Menyendiri (Solitude)}

Dalam Personal Narrative Edwards menceritakan peristiwa ketika ia merenungkan 1 Timotius 1:17 (Hormat dan kemuliaan sampai selama-lamanya bagi Raja segala zaman, Allah yang kekal, yang tak nampak yang esa! Amin). Ketika Edwards membaca kata-kata di ayat tersebut, jiwanya mengalami sensasi kemuliaan ilahi yang belum pernah ia alami sebelumnya. Setelah peristiwa itu, sambil tetap merenungkan mengenai Kristus dan kemuliaan ilahi-Nya, Edwards kerap berimajinasi sedang berada sendirian di pegunungan atau di tempat sepi di alam terbuka, jauh dari manusia lain. Di situ ia bercakap-cakap dengan Kristus dan sepenuhnya terserap di dalam relasi dengan Allah.

Imajinasi Edwards tentang solitude (menyendiri) di pegunungan itu bukan hanya sesuatu yang terjadi sekali saja, tapi memang merupakan karakteristik utama dari Edwards. Solitude adalah latihan rohani ketika seseorang dengan sengaja pergi menyendiri agar bisa fokus berinteraksi dengan Tuhan dan diri sendiri. Ketika ber-solitude, Edwards biasanya melakukan aktivitas membaca, berjalan-jalan di alam terbuka, dan berefleksi, yang pada akhirnya menolongnya untuk membangun konteks religius sebagai seorang teolog. Dengan demikian bagi Edwards, solitude merupakan elemen integratif dalam pencariannya akan transformasi pribadi, tempat dimana ia menemukan dirinya dan panggilannya. ${ }^{49}$

\section{Praktik Rohani: Memeriksa Diri atau Menguji Hati}

Seperti halnya kaum Puritan lain yang hidup di abad ke-18, Edwards sangat menekankan perlunya memeriksa diri atau menguji hati. Apalagi karena Edwards dan kaum Puritan pada umumnya percaya bahwa manusia seringkali membodohi dirinya, atau kalau menggunakan istilah jaman sekarang, hidup 'munafik'. Karena itu Edwards membahas tentang isu kemunafikan ini dalam Religious Affections dan meyakini bahwa pemeriksaan diri (self-examination) merupakan cara terbaik untuk mengatasi masalah ini. ${ }^{50}$

\footnotetext{
${ }^{47}$ McClymond, Encounters with God: An Approach to the Theology of Jonathan Edwards.

${ }^{48}$ Piper, God's Passion for His Glory: Living the Vision of Jonathan Edwards.

${ }^{49}$ W. Clark Gilpin, "Inward, Sweet Delight in God: Solitude in the Career of Jonathan Edwards," The Journal of Religion 82 (2002): 523-24.

${ }^{50}$ McClymond and McDermott, The Theology of Jonathan Edwards.
} 
Praktik Rohani: Menulis Jurnal

Kaum Puritan pada umumnya menuliskan jurnal dari apa yang mereka renungkan sebagai cara untuk bisa lebih mengenal diri. Bagi mereka, menulis itu sendiri merupakan bentuk praktik rohani tersendiri. Kita bisa melihat hal ini dari Diary. Di salah satu bagiannya, Edwards menuliskan tentang praktik merenungkan dengan cara menuliskan berbagai refleksinya. ${ }^{51}$ Dengan demikian dapat dipastikan bahwa menulis jurnal adalah bagian dari keseharian hidup Edwards. Jika sebagian dari naskah-naskah Edwards tidak rusak atau hangus akibat kebakaran, maka kemungkinan masyarakat Kristen dunia akan diberkati melalui berbagai refleksi mendalam dari tulisan jurnal Edwards.

\section{Praktik Rohani: Merenungkan Firman}

Firman Tuhan dan sumber-sumber bacaan rohani lainnya untuk kemudian direnungkan dan dicerna merupakan praktik rohani yang umum dilakukan oleh Kaum Puritan di masa Edwards hidup. Namun bagi seorang pengkhotbah, mempelajari dan merenungkan Firman bukan sekedar praktik umum tapi merupakan hal yang fundamental. Ketidak-pahaman akibat minimnya pemahaman akan Alkitab dapat menimbulkan keraguan akan kebenaran-Nya. ${ }^{52}$ Itulah sebabnya Edwards menyatakan bahwa perkembangan afeksi kudus tidak dapat terjadi tanpa pelayanan Firman yang secara teologis dipikirkan secara mendalam, tulus, dan berorientasi pada Alkitab. Karena itu dalam berbagai kesempatan Edwards menekankan pentingnya mempelajari dan merenungkan Firman Tuhan, apalagi jika seseorang adalah pengkhotbah, maka ia harus membaca dan mempelajari Firman Tuhan terlebih dahulu sebelum berkhotbah. ${ }^{53}$

\section{Praktik Rohani: Berdoa}

Edwards meyakini bahwa cara untuk mengarahkan hati pada Tuhan adalah melalui doa yang dinaikan secara tulus dan terus-menerus kepada Tuhan, sebab melalui proses ini Allah akan membuat manusia menjadi lebih sadar akan dosa, sehingga ia dapat merendahkan dirinya di hadapan Tuhan. ${ }^{54}$ Edwards membahas tentang doa secara mendalam antara lain di khotbahnya mengenai Mazmur 15. Di situ Edwards berkali-kali mengatakan bahwa Allah mendengarkan doadoa kita. Ia pun mendorong para pembacanya untuk berdoa agar Roh Allah tercurah di jiwa orangorang yang ada di seluruh muka bumi. ${ }^{55}$

Memang tidak terlalu banyak jejak tulisan otobiagrafi Edwards yang tertinggal. Namun dari apa yang tercatat mengenai bagaimana ia mempraktikan kehidupan imannya, diketahui bahwa spiritualitas Edwards bersifat teosentris dan kontemplatif. Disebut teosentris karena imannya berpusat pada Tuhan dan bukan pada kekuatan dirinya sendiri. Disebut kontemplatif

\footnotetext{
${ }^{51}$ McClymond, Encounters with God: An Approach to the Theology of Jonathan Edwards.

${ }^{52}$ Rubyantara Jalu Permana and Sonny Eli Zaluchu, "Penulis Loh Batu Kedua Sepuluh Perintah Allah,” PASCA : Jurnal Teologi Dan Pendidikan Agama Kristen 16, no. 1 (May 29, 2020): 24-32, https://doi.org/10.46494/psc.v16i1.71.

${ }^{53}$ Sean Michael Lucas, "Divine Light, Holy Heat: Jonathan Edwards, the Ministry of the Word, and Spiritual Formation," Presbyterian 34, no. 19 (2008): 2.

${ }^{54}$ Michael D. McMullen, ed., The Glory and Honor of God: Volume 2 of the Previously Unpublished Sermons of Jonathan Edwards (Nashville, TN: Broadman \& Homan, 2004).

55 Jonathan Edwards, "Sermon XVIII: The Most High A Prayer Hearing God, Psalm Lxv.2," in Works of Jonathan Edwards Vol VIII, n.d., 44-65.
} 
karena cara ia melayani dan menyenangkan hati Tuhan terutama diterapkan dengan merenungkan berbagai karakter dan karya Allah.

\section{KESIMPULAN}

Dari pemaparan di atas dapat disimpulkan bahwa afeksi yang dirujuk oleh Jonathan Edwards bukan hanya merujuk pada perasaan atau emosi saja seperti makna istilah ini dalam psikologi modern, walaupun hal itu merupakan salah satu unsurnya. Bagi Edwards, afeksi merupakan kehendak atau kecenderungan jiwa yang mempengaruhi pengambilan keputusan dari suatu tindakan. Di dalam prosesnya terdapat interaksi antara rasio dan emosi yang memunculkan kehendak. Itulah sebabnya, afeksi ini sering dirujuk oleh Edwards dengan istilah 'hati'.

Seseorang bisa pertama-tama mengalami afeksi kudus melalui anugerah Allah karena hal ini sepenuhnya merupakan karya Roh Kudus. Namun untuk selanjutnya, afeksi kudus bisa dibangun dengan cara menikmati keindahan Allah melalui relasi interaktif secara berkala antara orang Kristen dan Allah Tritunggal. Menikmati keindahan Allah bersifat esensial karena inilah yang mengubah orang Kristen menjadi semakin seperti Kristus.

Edwards mengistilahkan proses menikmati keindahan Allah ini sebagai latihan praktik Kristen. Penerapannya dapat dengan cara berdoa, menyendiri secara berkala agar bisa fokus berinteraksi dengan Tuhan, memeriksa diri atau menguji hati secara rutin, menulis jurnal, dan merenungkan Firman. Tentu saja, ada banyak cara lain untuk membangun afeksi kudus melalui berbagai wujud praktik rohani yang di masa kini umum diistilahkan sebagai disiplin rohani.

\section{REFERENSI}

Cherenkov, Michael. "5 Pandemic Lessons from Eurasia's Evangelical Churches." Christianity Today, July 2020.

Donald Wayne Viney. "American Deism, Christianity, and the Age of Reason." American Journal of Theology \& Philosophy 31, no. 2 (2010): 83-107. https://doi.org/10.1353/ajt.0.0005.

Edwards, Jonathan. A Treatise Concerning Religious Affections in Three Parts. Grand Rapids,

MI.: Christian Classics Ethereal Library, n.d.

—. "Sermon XVIII: The Most High A Prayer Hearing God, Psalm Lxv.2." In Works of Jonathan Edwards Vol VIII, 44-65, n.d.

Fromm, Erich. Mempunyai Atau Mengada. Edited by Muhammad Ali Fakih. Yogyakarta: IRCiSoD, 2019.

Gilpin, W. Clark. "Inward, Sweet Delight in God: Solitude in the Career of Jonathan Edwards." The Journal of Religion 82 (2002): 523-24.

Jehlen, Myra, and Michael Warner, eds. "Jonathan Edwards: Personal Narrative." In The English Literatures of American 1500 - 1800, 609. New York and London: Routledge, 1997.

KBBI Daring. “Afeksi,” n.d.

Kristianto, Paulus Eko. "Memahami Konstruksi Teologi Keindahan.” KURIOS (Jurnal Teologi Dan Pendidikan Agama Kristen) 5, no. 2 (2019): 151-65.

Kuruvilla, Carol. “Evangelical Songwriter Says He's No Longer Christian In Emotional 
Instagram Post." Huffpost.com, 2019.

Lucas, Sean Michael. "Divine Light, Holy Heat: Jonathan Edwards, the Ministry of the Word, and Spiritual Formation." Presbyterian 34, no. 19 (2008): 2.

Marsden, George A. "Biography." In The Cambridge Companion to Jonathan Edwards, edited by Stephen J. Stein, 23. Cambridge: Cambridge University Press, 2007.

McClymond, Michael J. Encounters with God: An Approach to the Theology of Jonathan Edwards. New York: Oxford University Press, 1998.

McClymond, Michael J., and Gerald R. McDermott. The Theology of Jonathan Edwards. Oxford: Oxford University Press, 2012.

McDermott, Gerald R. "Introduction: How to Understand the American Theologian." In Understanding Jonathan Edwards: An Introduction to America's Theologian. Oxford: Oxford University Press, 2009.

_. "Jonathan Edwards, Deism, and the Mystery of Revelation." Journal of Presbyterian History (1997) 77, no. 4 (1997): 211-24.

McMullen, Michael D., ed. The Glory and Honor of God: Volume 2 of the Previously

Unpublished Sermons of Jonathan Edwards. Nashville, TN: Broadman \& Homan, 2004.

Permana, Rubyantara Jalu, and Sonny Eli Zaluchu. "Penulis Loh Batu Kedua Sepuluh Perintah

Allah.” PASCA : Jurnal Teologi Dan Pendidikan Agama Kristen 16, no. 1 (May 29, 2020):

24-32. https://doi.org/10.46494/psc.v16i1.71.

Piper, John. God's Passion for His Glory: Living the Vision of Jonathan Edwards. Wheaton: Crossway Books, 1998.

- Mendambakan Allah: Meditasi Seorang Hedonis Kristen. Edited by Elifas Gani. Surabaya: Penerbit Momentum, 2008.

Porter, Steve L. "The Willardian Corpus." Journal of Spiritual Formation and Soul Care 3, no. 2 (2010): 239-66.

Stratchan, Owen, and Doug Sweeney. Jonathan Edwards on Beauty. Chicago: Moody Publishers, 2010.

Sukono, Djoko. “Teologi 'Manusia Baru' Relevankah Di Era Milenial.” PASCA: Jurnal Teologi Dan Pendidikan Agama Kristen 15, no. 2 (2019): 39-44.

Thomforde, James H. "Defending Happiness: Jonathan Edwards's Enduring Pursuit of a Reformed Teleology of Happiness." The University of Edinburgh, 2018.

Yayasan Lembaga SABDA. "Farisi." Studi Kamus Alkitab SABDA, n.d.

Zaluchu, Sonny Eli. "Strategi Penelitian Kualitatif Dan Kuantitatif Di Dalam Penelitian Agama.” Evangelikal: Jurnal Teologi Injili Dan Pembinaan Warga Jemaat, 2020. https://doi.org/10.46445/ejti.v4i1.167. 